\title{
岩の伝熱および熱水浸透流による熱拡散係数の実験的研究

\author{
EXPERIMENTAL DETERMINATION OF ROCK THERMAL DIFFUSIVITIES \\ WITH DIFFERENT HYDRAULIC CONDITIONS
}

\author{
佐 藤邦 明*・佐々木康夫** \\ By Kuniaki SATO and Yasuo SASAKI
}

\begin{abstract}
When we deal with the heat transfer problems in rock ground, the evaluation of heat transfer parameters becomes important as well as the determination of hydraulic parameters such as the permeability and storage coefficient. This paper presents how to determine the thermal diffusivity of rocks having different hydraulic conditions in a laboratory, and the values of thermal diffusivities with six kinds of rocks collected from different locations in this country were determined by using two inherent apparatuses. The utility of the apparatuses proposed in this paper was confirmed, and the rock thermal diffusivities were $0.333 \times 10^{-6} \sim 1.19 \times 10^{-6} \mathrm{~m}^{2} / \mathrm{s}$ for many kinds of rocks.
\end{abstract}

\section{1.はじめに}

地熱, 地下エネルギー工学的諸問題などに係って岩石, 岩盤中の伝熱, 熱水水理問題は重要性を増しつつある. この種の熱諸問題を扱う際，熱拡散係数や熱伝導率など の伝熱パラメーターは基本的に大切となり，技術的のみ ならず科学的にも岩種や水理条件によってどうなるかあ らかじめ知っておく必要がある. 従来, 熱拡散係数と熱 伝導率はほとんど定常伝熱によって，特定の多孔体や岩 石について実験的に決定された経過がある.たとえば, Kunii, D. and Smith, J.M. (1961) ${ }^{11}$, Combarnous, M. and Bories, S. $(1975)^{2)}$, 松本 ·大久保 $(1977)^{3)}$, 佐藤・佐々木 $(1984)^{4)}$ によるものがある. 一方, 最近 に至って,これらパラメーターを非定常伝熱実験によっ て決定したものに，佐藤 $(1982)^{5)}$, Firdauss, M. , Maalej, M. and Belin, B. $(1983)^{6)}$, 佐藤 ·佐々木 $(1983)^{7)}$ がみられる.しかし, 岩の風化の程度, 含水状態, さらに熱水浸透流を伴う場合に伝熱パラメーターがどう なるか, 実験的研究が望まれているのが現状である.

\footnotetext{
* 正会員 工博 埼玉大学助教授 工学部地盤水理実験施設 （元336 埼玉県浦和市下大久保 255）

** 正会員 三菱金属(株)中央研究所（埼玉大学研究生）

（ ₹330 埼玉県大宮市北袋町 1-297）
}

物理学的に, 岩の伝熱は岩質部分の伝熱, 割れ目・ク ラック系の流体伝熱, 移流伝熱, 流体と岩質間の熱交換, および輻射からなる。しかし，周知のように岩石の場合， 空隙率は砂やガラス球充てん層のようなものに比べて十 分小さいから，伝導とクラック・割れ目中の流体伝熱が 支配的となる．いうまでもなくクラックや割れ目系の構 造は風化や岩石の生成プロセスに依存し，伝熱は水理条 件（たとえば今水状態，移流など）にも関係してくる. 従来得られている伝熱パラメーターの值自体は乾燥状態 でしかも限られた岩種についてのみにすぎず，実用上伝 熱方程式を現地へ応用しようとする際, いろいろな岩種, 水理条件における値が包括的に必要となってくる.

本研究はこのような背景にあって，特殊に設計された 2 種類の岩伝熱装置を用いて, 本邦で代表的と思われる 6 種の岩石を採取し, 新鮮岩, 風化岩に関して水理条件 をいろいろ変えて 66 個の岩石サンプルの伝熱パラメー ターを実験的に決定した。そこで，これら多数の実験結 果を実用上使いやすいように整理した．非定常伝熱に よって岩の伝熱パラメーターをどのように決定するか 之, 併せ得られた値が実際上大変有効であると思われた のでここに報告する. 


\section{2. 実験に用いる基礎式とその解}

一般に，岩盤自身は岩質とクラック・割れ目からなっ ており, 乾燥状態で熱はこの両者を同時に伝わる.もし, 岩盤が水に飽和されたとすれば, 熱は岩石, クラック・ 割れ目系のみならず，流体や対流によっても伝わる．周

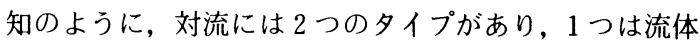
密度差によるいわゆる自然対流であり, 他は強制対流で ある．普通の岩石では空隙率が小さく，クラック系の間 隙寸法も大きくないから, 自然対流は発生・成長しにく い. そこで, 小クラック程度を含む乾燥岩石や水で満た された飽和岩石の伝熱を取り扱う場合，そのような小ク ラックの影響や局部的な伝熱の異方性を平均化した等価 パラメーターを導入して，均質・連続固体の伝熱と同様 に扱うと便利である。この考え方を導入すれば，均質・ 連続固体の一次元伝熱にフーリエの伝熱方程式を適用す ることが可能となり，クラックの存在や飽和水の伝熱に 与える影響を熱拡散係数によって量的に簡便評価するこ とができる。

一方, 岩盤中を熱水が浸透しつつ伝熱するような場合 は流れによる強制対流が上述の伝熱に加えて起こること になる.こういった場合はフーリエの伝熱方程式に対流 項を付加した伝熱方程式が適用し得ることとなる.この ようなことを踏まえて本論の実験では次の 2 つの場合に 分けて伝熱実験を行い, 別々の基礎式の条件から解を得 て，適用する.

1) 均質・連続固体の伝熱

2) 強制対流項のある均質・連続固体の伝熱

以下これら $2 つ$ つ場合の基礎式, 条件および解を提示 しておくこととしよう.

（1）均質・連続固体の伝熱方程式とその解

もし岩石が均質・連続固体とすれば, 伝熱方程式は, $\frac{\partial T}{\partial t}=a \frac{\partial^{2} T}{\partial x^{2}} \quad a=\frac{x}{\rho c}$

となる.ここに, $T$ : 温度, $t$ : 時間, $x$ : 座標, $x$ : 熱 伝導率, $c, \rho:$ おおの等価比熱, 密度, $a$ : 熱拡散係 数である.

式（１）の伝熱パラメーターは含水状態, 岩種, クラッ ク・割れ目の存在によって変わる. 式（1）の解は条件 $x=0, \quad T=T_{0}, \quad t \geqq 0$ $x=l, \quad T=T_{l}, \quad t \geqq 0$

$$
t=0, \quad T=T_{i}, \quad x>0
$$

のもとで

$$
\begin{aligned}
\frac{T-T_{0}}{T_{l}-T_{0}}= & \frac{x}{l}+\frac{4}{\pi} \cdot \frac{\left(T_{i}-T_{0}\right)}{\left(T_{l}-T_{0}\right)} \cdot \sum_{s=1}^{\infty} \frac{1}{(2 s-1)} \\
& \cdot e^{-a \frac{(2 s-1)^{2} \pi^{2}}{l^{2}} \cdot t} \cdot \sin \frac{(2 s-1) \pi}{l} x
\end{aligned}
$$

$$
\begin{aligned}
& +\frac{2}{\pi} \sum_{s=1}^{\infty} \frac{(-1)^{s}}{s} \cdot e^{-a \frac{s^{2} \pi^{2}}{l^{2}}} \cdot \sin \frac{s \pi}{l} x \\
& (s=1,2,3, \cdots) \ldots \ldots \ldots \ldots \ldots \ldots \ldots \ldots \ldots \ldots \ldots \ldots \ldots \ldots \ldots
\end{aligned}
$$

となる.ここに, $T_{0}, T_{l}:$ おのおの $x=0$, および $x=l$ での境界温度であり, $T_{i}: t=0$ での初期温度, $l:$ 岩石 試料の長さ,である.

\section{（2）強制対流項のある均質・連続固体の伝熱方程式 とその解}

岩石が均質・連続固体であるとし，一方向一様強制対 流があるとすれば，一次元伝熱方程式は

$$
\frac{\partial T}{\partial t}+\frac{(\rho c)_{f}}{(\rho c)} u \frac{\partial T}{\partial t}=\frac{\varkappa}{(\rho c)} \cdot \frac{\partial^{2} T}{\partial x^{2}}
$$

となる.ここで, $u$ : 平均移流速度, 添字 $f$ は流体の熱 容量値を表わす.

式（4）において, 一定移流速 $u$ は温度の違った流 体が飽和岩石中へ浸入する流速であり, 左辺第 2 項の $(\rho c)_{s} /(\rho c)$ は流れている流体の熱容量 $(\rho c)_{f}$ 之流体・岩 石の共存状態における熱容量 $(\rho c)$ の比を表わし, 熱伝 導率 $\boldsymbol{1}$ はすでに述べた等価値である.式（4）の解は 条件

$$
\begin{aligned}
& X=0, \quad \theta=1, \quad \tau \geqq 0
\end{aligned}
$$

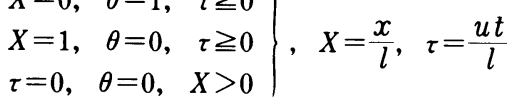

$$
\begin{aligned}
& \zeta=\frac{a}{l u}, \quad \varepsilon=\frac{(\rho c)_{f}}{(\rho c)}, \quad \theta=\frac{\left(T-T_{l}\right)}{\left(T_{0}-T_{l}\right)}
\end{aligned}
$$

のもとで

$$
\begin{aligned}
\theta= & \frac{e^{\frac{\varepsilon}{\xi} x}-e^{\frac{\varepsilon}{\xi}}}{1-e^{\frac{\varepsilon}{\zeta}}}-\sum_{s=1}^{\infty} \frac{2}{s \pi} \frac{1}{\left\{\left(\frac{\varepsilon}{2 \zeta s \pi}\right)^{2}+1\right\}} \\
& \cdot e^{\frac{\varepsilon}{2 \zeta} x} \cdot \sin (s \pi x) \cdot e^{-\zeta\left\{s^{2} \pi^{2}+\left(\frac{\varepsilon}{2 \xi}\right)^{2}\right\}} \ldots \ldots .
\end{aligned}
$$

のようになる5!.

式（3）と（6）功熱拡散係数の值を決定するため には理論条件式（2），（5）と同じ条件下で実験を行い, 岩石試料中の温度の経時変化と解曲線を比較して best fit curve を得る手順が合理的である.

\section{3. 実験装置，実験方法および岩石試料}

岩石の熱拡散係数を決定するため， 2 種の伝熱実験が 行われるが, 装置の詳細および実験方法はおのおの次の ようである.

\section{（1）岩石の伝熱実験装置}

Fig. 1 (a) は乾燥, 飽和岩石の伝熱を計る実験の装置 の概略である.

本装置は, (1)熱水タンク（直径 $0.30 \mathrm{~m}$, 高さ $0.30 \mathrm{~m}$ の鋼鉄製であり定温熱源), (2)電気ヒーター(電圧 $200 \mathrm{~V}$, 容量 $5 \mathrm{~kW}$ ), (3)岩石試料 (直径 $0.055 \mathrm{~m}$, 高さ $0.15 \mathrm{~m}$ ), (4)下部定温デスク（直径 $0.055 \mathrm{~m}$, 高さ $0.055 \mathrm{~m}$ の鋼鉄 


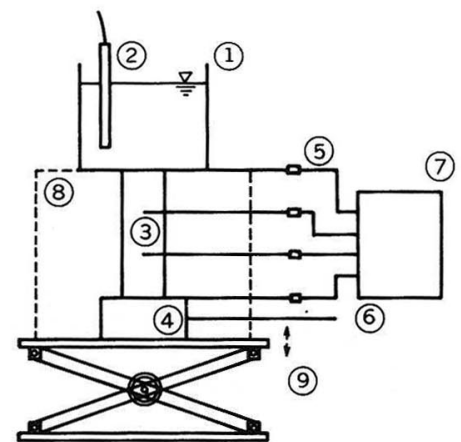

(a) System of measurement

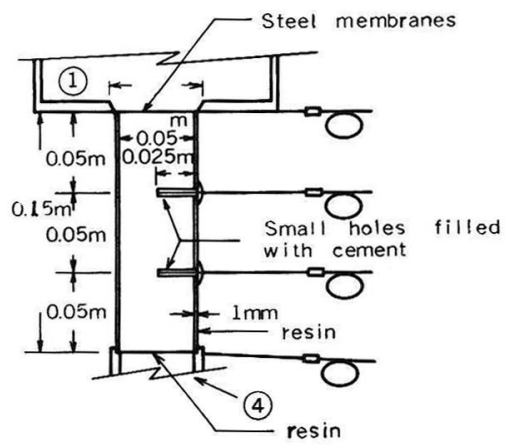

(b) Detail of rock sample setting

Fig. 1 Schematic presentation of apparatus for measuring heat conduction of rock.

製であり定温源)，(5)サーミスターセンサー（直径 3.2 $\mathrm{mm}$, 長さ $0.25 \mathrm{~m}$ ), (6)冷却水, (7)自動温度記録計 (夕 カラ自動温度集録装置 $\mathrm{K}-700,36$ チャンネル, $0.10^{\circ} \mathrm{C}$ 精度), (8)断熱材 (発泡スチロール), (9)可動台 (ホイー ルの回転により鉛直方向上下動可能である).これらの 装置は 1. で述べた理論境界条件式（2）と同じ条件を 与えるように作られており，(2)電気ヒーターによって熱 水タンク中の水は $100^{\circ} \mathrm{C}$ の定温に保たれ, 岩石試料の 下端は定温水の循環する下部定温デスクによって一定温 度に保たれる. また, 岩石試料中の温度の経時変化は 2 本のサーミスターセンサーにより計られ，試料上下端の 定温は念のため 2 本のセンサーによって確かめられる. サーミスターセンサーは岩石の上端から $0.05,0.10 \mathrm{~m}$ の点の深さ $0.025 \mathrm{~m}$ の直径 $4.0 \mathrm{~mm}$ の小孔中に設置さ れ,センサー元端から樹脂で充てん，埋め込まれる(Fig. 1 (b) 参照).

実験は次の手順で行われる．まず，乾燥岩石試料か飽 和岩石試料かのいずれかにサーミスターセンサーを所定 の位置に設置した後，断熱材中へ収納して，下部定温デ スクに試料下部が接着固定される，次に自動温度記録装

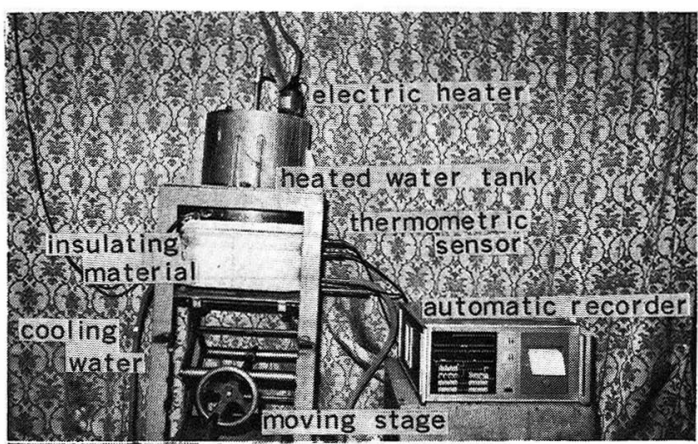

Photo 1 Picture of apparatus for measuring thermal diffusivity of dried and saturated rocks.

置を結線した後, 可動台上に岩石試料が置かれ, 可動台 にあるホイールの回転によって岩石試料の上面が熱水夕 ンクの下面に接触される.この岩石試料の上面と熱源と の接触抵抗を少なくするため, Fig.1(b) のように薄い メンブレンが用いられた．このようにして，岩石中と境 界の温度の経時変化が計られる.

Photo 1 には実験装置の全景を示し, 各部の名称も示 されている.

\section{（2）浸透流を伴う伝熱実験装置}

Fig. 2(a) は浸透流（熱水の強制対流）を伴う伝熱の 実験装置の概略を示したものである.

実験装置の詳細とそのシステムは次のようである.

(1)ガスタンク (浸透流の水圧を発生させるために用い, 窒素ガスで最大発生ガス圧は $\left.14.7 \mathrm{MN} / \mathrm{m}^{2}\right)$, (2)圧力夕 ンク (ガスタンクから導かれた窒素ガス圧をゴムバルー ンの膨張に変えて水圧を得る, 直径 $0.30 \mathrm{~m}$, 高さ 0.50 $\mathrm{m}$ の鋼鉄製)，(3)圧力調整バルブ，(4)，(5)バルブ，(6)熱 水タンク (直径 $0.30 \mathrm{~m}$, 高さ $0.30 \mathrm{~m}$ ), (7)水圧デスク (高 水圧の浸透熱水源となり, 直径 $0.06 \mathrm{~m}$, 高さ $0.06 \mathrm{~m})$, (8)岩石試料（直径 $0.055 \mathrm{~m}$, 高さ $0.15 \mathrm{~m}$ ), (9)下部定温 デスク（直径 $0.06 \mathrm{~m}$, 高さ $0.055 \mathrm{~m}$ ), (10)+ーミスター センサー（直径 $3.2 \mathrm{~mm}$, 長さ $0.25 \mathrm{~m}$ ), (11)自動温度記 録計 (夕カラ自動温度集録装置 K-700, 36 チャンネル, $0.10^{\circ} \mathrm{C}$ 精度), (12)冷却水, (13)メスシリンダー, (14)断熱材, (15)電気ヒーター (電圧 $200 \mathrm{~V}$, 容量 $5 \mathrm{~kW}$ ), (16)可動台, からなっている. (6)に示した熱水タンクは沸騰を伴う熱 水で $100^{\circ} \mathrm{C}$ に保たれる. また，岩石試料の断熱，およ びサーミスターセンサーの設定位置は Fig. 2(b) に示し たようである.

実験の手順は次のようである，まず，岩石試料は純水 中で完全に飽和させた後, サーミスター挿入孔に水が満 たされた状態でセンサーを挿入し，樹脂で充てん設置す る. 断熱材に岩石試料を収納したら，下部定温デスクに 試料下面を密着固定させる，そこで, 岩石試料を可動台 


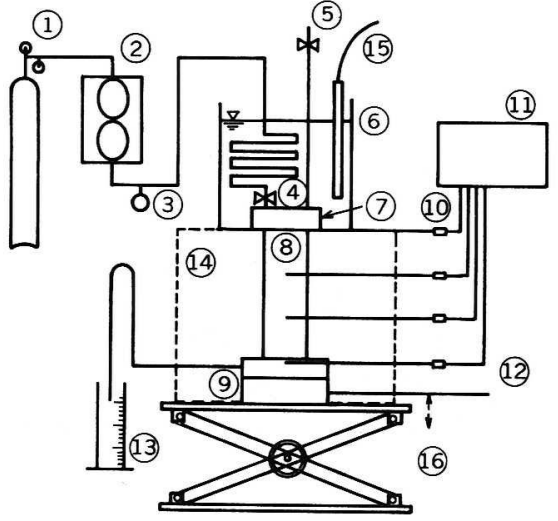

(a) System of measurement

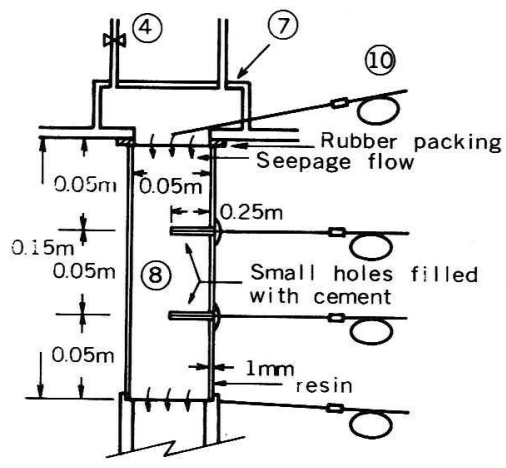

(b) Detail of rock sample

Fig. 2 Schematic presentation of apparatus for measuring heat conduction accompanied with seepage flow in rock.

に置き, 可動台のホイールを回転させて, 温度自動記録 装置を稼動させるやいなや岩石試料上端を水圧デスクに 圧着・固定する。ついですみ やかに熱水バルブを開放して 熱水浸透を起こして, 浸透流 を伴う伝熱による岩石試料中 の温度の経時変化を測定する わけである。

Fig. 2(b) を参照して, 岩 石試料の最上部の水密, 下端 の定温条件の仕方, および サーミスターセンサーの設定 状態を知ることができる，熱 水の浸透流量はメスシリン ダーもしくはビューレットで 計ることができる.

Photo 2 は実験装置の全景 を各部の名称とともに示して いる.

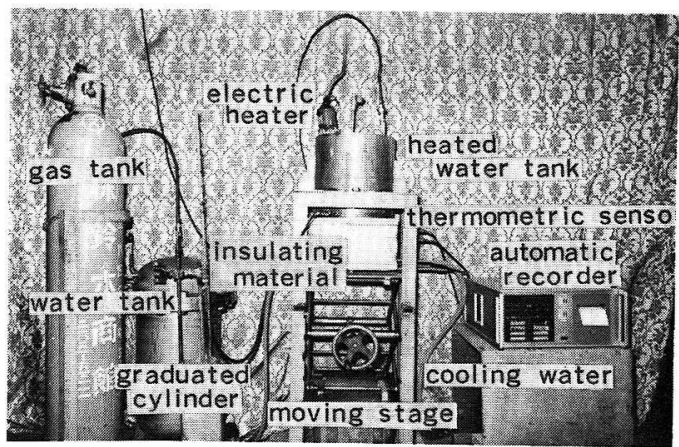

Photo2 Picture of apparatus for measuring diffusivity of rock sample accompanied with seepage flow.

\section{（3）岩石試料と岩石物性}

伝熱実験には 6 種の岩石試料が用いられた。これら岩 石は本邦 8 か所から採取された代表的岩石である。岩石 は凝兏岩亡して福島県産の白河, 江持凝灰岩, 杤木県産 の大谷凝灰岩, 花崗岩として岡山県産と茨城県産の花崗 岩, 兵庫県産の玄武岩, 千葉県産の粗粒, 細粒砂岩, 和 歌山県産の頁岩, 神奈川県産の安山岩である. 実験に用 いられたすべての岩石試料は 2 種類に大別される. 1 つ は採取されたままの自然状態（新鮮）のもの，他は実験 室内における加熱 $\left(600^{\circ} \mathrm{C}\right.$, または $\left.200^{\circ} \mathrm{C}\right)$ と冷却 $\left(15^{\circ} \mathrm{C}\right)$ を履歴させた，いわゆる人工強熱風化と呼ばれるもので ある.

Table 1 (a) には岩石試料の吸水率, 空隙率, 透水係数, 比熱, 密度などの物性が一括示されている。一般的には 強熱風化によって吸水率, 空隙率, 透水係数は増加し, 密度は減少する. また, 岩石の色彩は強熱風化によって 変化する.
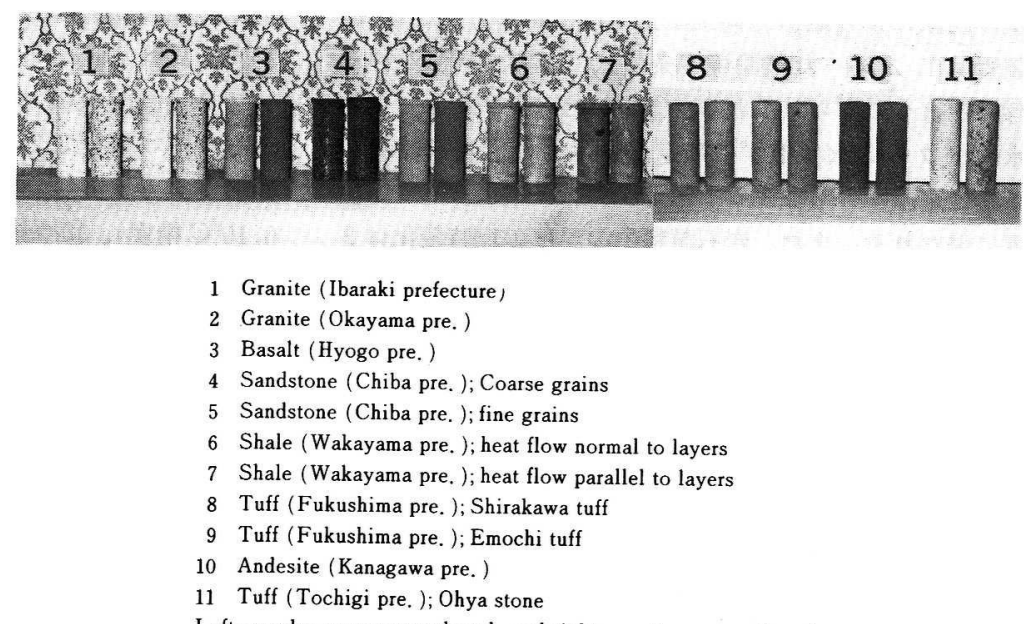

Left samples are non-weathered, and right samples are weathered.

Photo 3 Test samples of rocks. 
岩石試料は約 1 週間純水で脱気飽和させ, 浸透流を伴 う伝熱の場合には $1 \mathrm{~mm}$ の厚さに樹脂で円周方向を被覆 し，加圧による漏水を防止している．空隙率，吸水率の 測定はいわゆる液浸法によった，伝熱物性として大切と なる比熱は，容量 $2.5 \times 10^{-3} \mathrm{~m}^{3}$ の断熱ボックスを用いて 求めた。 それは，断熱ボックス中に純水を入れ，加熱岩 石を投入し，十分時間が経過後の温度を計ると，次式に よって比熱 $c$ は

$$
c=\frac{m_{w}\left(T_{2}-T_{1}\right)}{m_{s}\left(T_{0}-T_{s}\right)}
$$

より求まる.ここに, $m_{w}, m_{s}$ ：おのおの純水および岩 石試料の質量, $T_{0}$ : 岩石試料の初期温度, $T_{1}, T_{2}$ : お のおの純水の初期, 終期温度である. すべての岩石試料 66 個の岩石物性は Table 1 にまとめて示されており, 自然岩石 33 個，人工強熱風化 33 個であった，岩石試料 はPhoto3に番号を付して示したので概観することがで きよう. 各番号の左側が自然状態のものであって，右側 が強熱風化したもので，風化によって色彩が変化してい ることがわかる.

\section{4. 実験結果と熱拡散係数の決定}

全岩石試料 66 個について武料中 2 点で温度の経時変 化が計られたわけであるが, それら測定結果は非常に似 たものになっているので乾燥状態, 飽和状態および熱水 浸透を伴う伝熱経時変化の代表的な結果として, 砂岩の 場合の結果を Fig. 3 に示すこととした. 温度の経時変化 を測定した位置は岩石試料上端から $x_{1}=0.05 \mathrm{~m}, x_{2}=$ $0.10 \mathrm{~m}$ である.

温度の経時変化は乾燥, 飽和状態の場合は十分時間が 経過した定常状態では, $T=T_{0}+\left(T_{1}-T_{0}\right) \cdot x / l\left(T_{0}\right.$, $T_{1}$ : おのおの岩石試料の初期, 終期温度）となる. す べての実験結果からすると，定常状態に至る時間は3 4 時間後であった。また，すべての実験結果によると， $x=0.05 \mathrm{~m}, x=0.10 \mathrm{~m}$ 点での実測定常温度は理論のそ れらと $5 \%$ 以内で合致していた. Fig. 3(a) は乾燥状 態における自然状態試料 $S_{a}-1, S_{a}-3$ の温度の経時変 化を示している. 試料 $S_{a}-1$ と $S_{a}-3$ の違いはおのお の粗粒, 細粒岩の違いがあるだけであるが, $S_{a}-3$ の経 時変化は $S_{a}-1$ のそれより構成粒子が細粒のため, 温 度の時間増加率が大きいことがわかる.これは岩石の構 造や造岩鉱物によって伝熱速度が違ってくることをはっ きり示しているものといえよう.

Fig. 3(b) は同様に飽和状態における温度の経時変化 を示したものであるが, これらによると, 乾燥状態にお ける温度の経時変化に比べて飽和水の存在のため温度の 時間増加率が大きいことが注目される.さらに, Fig. 3(c) は風化砂岩 $S_{a}-2, S_{a}-4$ の場合の浸透流を伴う温度の
経時変化を示したものである.これらの結果は初期にお ける温度の経時変化を示しているが，時間が経過するに つれて浸透熱水のフロントが通過してしまうため, 後述 する熱拡散係数決定の都合もあって 0 24 分間の変化を 描いたものである.

そこで，1. で述べた式（3)，式（6）を用いて熱拡 散係数 $a$ の值を乾燥, 飽和状態および浸透流を伴う場 合について求めてみることとする.

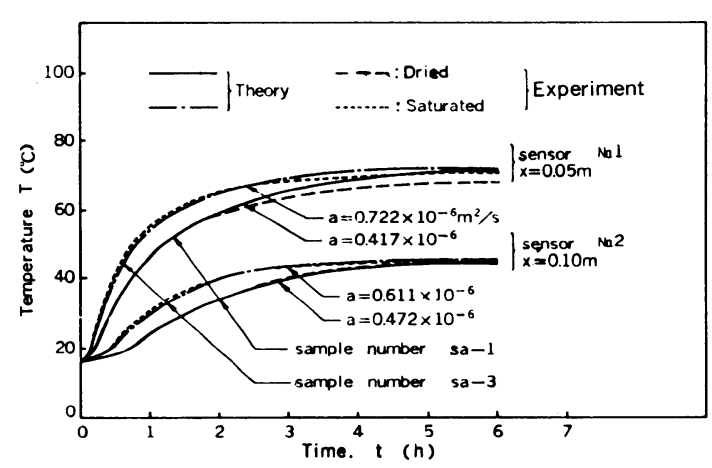

(a) Temperature change with time of non-weathered sandstone in case of dried and saturated conditions.

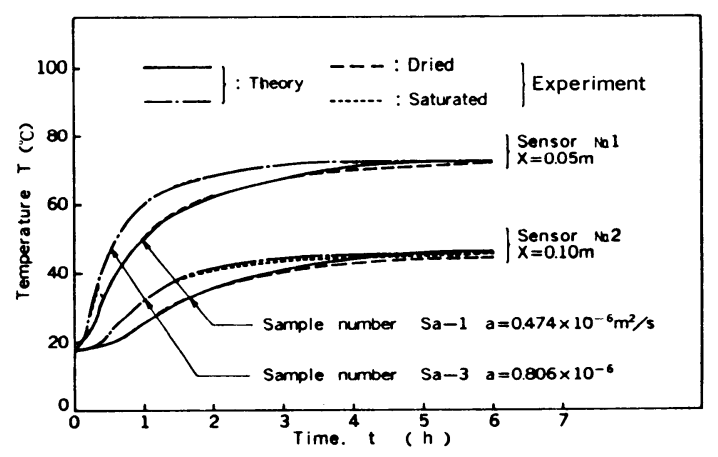

(b) Temperature change with time of weathered sandstone in case of dried and saturated conditions.

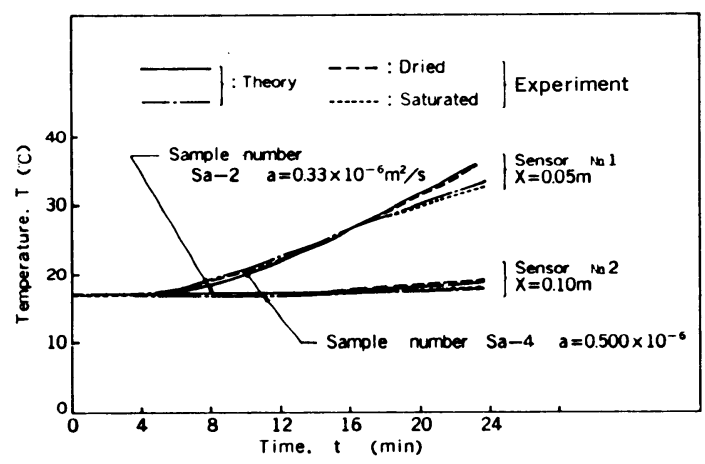

(c) Temperature change with time accompanied with seepage flow in case of sandstone.

Fig. 3 Some results of temperature change with time and best fitting curves. 
Table 1 Rock sample properties and results of measurement.

(a) Rock samples and their properties

\begin{tabular}{|c|c|c|c|c|c|c|c|c|c|c|}
\hline $\begin{array}{l}\text { Name of } \\
\text { rocks }\end{array}$ & $\begin{array}{l}\text { Sampling } \\
\text { locations }\end{array}$ & $\begin{array}{l}\text { Somple } \\
\text { number }\end{array}$ & $\begin{array}{l}\text { Weathering } \\
\text { conditions }\end{array}$ & $\begin{array}{c}\text { Testing } \\
\text { conditions }\end{array}$ & $\begin{array}{l}\text { Water } \\
\text { absorbing } \\
\text { capocity } \\
\text { (\%) }\end{array}$ & $\begin{array}{c}\text { Porosity } \\
\text { (\%) } \\
\end{array}$ & $\begin{array}{c}\text { density } \\
\left(\times 10^{3} \mathrm{~kg} / \mathrm{m}^{3}\right)\end{array}$ & $\begin{array}{c}\text { Permea- } \\
\text { bility } \\
(\mathrm{m} / \mathrm{s})\end{array}$ & $\begin{array}{l}\text { Soeppage } \\
\text { Volocity } \\
(\mathrm{m} / \mathrm{s})\end{array}$ & $\begin{array}{c}\begin{array}{c}\text { Specific } \\
\text { heat } \\
\text { (KU/kgK) }\end{array} \\
\end{array}$ \\
\hline \multirow{4}{*}{ Granites } & \multirow{2}{*}{$\begin{array}{l}\text { Ibaraki } \\
\text { Prefecture }\end{array}$} & G - 1 & $\begin{array}{c}\text { non- } \\
\text { Weather ed }\end{array}$ & \begin{tabular}{|c|} 
dried \\
Saturated \\
Seepage
\end{tabular} & $\begin{array}{l}0.228 \\
0.228 \\
0.228\end{array}$ & $\begin{array}{l}0.603 \\
0.603 \\
0.603\end{array}$ & $\begin{array}{l}2.64 \\
2.64 \\
2.64\end{array}$ & $\longrightarrow$ & - & $\begin{array}{l}0.808 \\
0.816 \\
0.816\end{array}$ \\
\hline & & $G-2$ & $\begin{array}{c}\text { Weathered } \\
(600 \mathrm{C})\end{array}$ & \begin{tabular}{|c|} 
dried \\
Saturat tod \\
Seopage \\
\end{tabular} & \begin{tabular}{|l|}
$1.85(0.322)$ \\
$1.85(0.322)$ \\
$1.85(0.322)$ \\
\end{tabular} & \begin{tabular}{|l|}
$4.69(0.874)$ \\
$4.69(0.874)$ \\
$4.69(0.874)$ \\
\end{tabular} & $\begin{array}{l}253 \\
258 \\
2.58 \\
\end{array}$ & $1.45 \times 10^{-8}$ & $9.00 \times 10^{-6}$ & $\begin{array}{l}0.833 \\
0.846 \\
0.846\end{array}$ \\
\hline & \multirow{2}{*}{$\begin{array}{l}\text { Okayamo } \\
\text { Prefecture }\end{array}$} & $G-3$ & $\begin{array}{c}\begin{array}{c}\text { non- } \\
\text { Weathered }\end{array} \\
\end{array}$ & \begin{tabular}{c|} 
dried \\
Saturated \\
Seepage
\end{tabular} & $\begin{array}{l}0.229 \\
0.229 \\
0.229 \\
\end{array}$ & $\begin{array}{l}0.777 \\
0.777 \\
0.777 \\
\end{array}$ & $\begin{array}{l}2.60 \\
2.61 \\
2.61 \\
\end{array}$ & - & $\longrightarrow$ & $\begin{array}{l}0.829 \\
0.804 \\
0.804 \\
\end{array}$ \\
\hline & & $G-4$ & $\begin{array}{c}\text { Weathered } \\
\left(600^{\circ} \mathrm{C}\right)\end{array}$ & \begin{tabular}{|c|} 
dried \\
Sotur at tod \\
Soepage
\end{tabular} & \begin{tabular}{|l|}
$1.79(0.475)$ \\
$1.79(0.475)$ \\
$1.79(0.475)$ \\
\end{tabular} & $\begin{array}{l}4.49(1.23) \\
4.49(1.23) \\
4.49(1.23) \\
\end{array}$ & $\begin{array}{l}2.51 \\
255 \\
255 \\
\end{array}$ & $1.24 \times 10^{-6}$ & $1.71 \times 10^{-5}$ & $\begin{array}{l}0.854 \\
0.908 \\
0.908 \\
\end{array}$ \\
\hline \multirow{2}{*}{ Basalt } & \multirow{2}{*}{$\begin{array}{l}\text { Hyogo } \\
\text { Prefecture }\end{array}$} & B - 1 & $\begin{array}{c}\text { non- } \\
\text { Weathered }\end{array}$ & \begin{tabular}{|c|} 
dried \\
Saturatted \\
Seepage
\end{tabular} & $\begin{array}{l}2.63 \\
2.63 \\
2.63 \\
\end{array}$ & $\begin{array}{l}6.24 \\
6.24 \\
6.24 \\
\end{array}$ & $\begin{array}{l}2.38 \\
2.44 \\
2.44\end{array}$ & - & $\longrightarrow$ & $\begin{array}{l}0.854 \\
0.908 \\
0.908\end{array}$ \\
\hline & & $B-2$ & $\begin{array}{c}\text { Weather ed } \\
(600 \mathrm{C})\end{array}$ & $\begin{array}{c}\text { dried } \\
\text { Saturatted } \\
\text { Soepage }\end{array}$ & $\begin{array}{l}6.29(3.56) \\
6.29(3.56) \\
6.29(3.56) \\
\end{array}$ & $\begin{array}{l}14.7(5.45) \\
14.7(5.45) \\
14.7(5.45)\end{array}$ & $\begin{array}{l}2.34 \\
2.49 \\
2.49\end{array}$ & $1.16 \times 10^{-8}$ & $1.71 \times 10^{-6}$ & $\begin{array}{l}0.862 \\
0.917 \\
0.917\end{array}$ \\
\hline \multirow{4}{*}{$\begin{array}{l}\text { Sand- } \\
\text { Stones }\end{array}$} & \multirow{2}{*}{$\begin{array}{c}\text { Chiba } \\
\text { Prefecture } \\
\text { (Coarse } \\
\text { gains) }\end{array}$} & $S a-1$ & $\begin{array}{c}\text { non- } \\
\text { Weathered }\end{array}$ & \begin{tabular}{|c|} 
dried \\
Saturat ted \\
Seepage
\end{tabular} & $\begin{array}{l}24.4 \\
24.4 \\
24.4 \\
\end{array}$ & $\begin{array}{l}40.2 \\
40.2 \\
40.2 \\
\end{array}$ & $\begin{array}{l}1.65 \\
2.05 \\
2.05 \\
\end{array}$ & $3.82 \times 10^{-5}$ & $5.02 \times 10^{-5}$ & $\begin{array}{l}1.005 \\
1.532 \\
1.532 \\
\end{array}$ \\
\hline & & $S a-2$ & $\begin{array}{c}\text { Weather ed } \\
(600 \mathrm{C})\end{array}$ & \begin{tabular}{|c|} 
dried \\
Saturated \\
Seepage \\
\end{tabular} & $\begin{array}{l}23.8(22.8) \\
23.8(22.8) \\
23.8(22.8) \\
\end{array}$ & $\begin{array}{l}40.1(39.0) \\
40.1(39.0) \\
40.1(39.0)\end{array}$ & $\begin{array}{l}1.68 \\
2.09 \\
2.09\end{array}$ & $6.24 \times 10^{-6}$ & $805 \times 10^{-6}$ & $\begin{array}{l}0.887 \\
1.302 \\
1.302 \\
\end{array}$ \\
\hline & \multirow{2}{*}{$\begin{array}{l}\text { Chiba } \\
\text { Prefecture } \\
\text { (fine } \\
\text { grains) }\end{array}$} & $S a-3$ & \begin{tabular}{|c|} 
non- \\
Weathered
\end{tabular} & \begin{tabular}{|c|} 
driod \\
Satur ated \\
Soepage
\end{tabular} & $\begin{array}{l}10.4 \\
10.4 \\
10.4 \\
\end{array}$ & $\begin{array}{l}20.5 \\
20.5 \\
20.5 \\
\end{array}$ & $\begin{array}{l}1.98 \\
2.18 \\
2.18 \\
\end{array}$ & & $\longrightarrow$ & $\begin{array}{l}0.883 \\
1.130 \\
1.130 \\
\end{array}$ \\
\hline & & $S a-4$ & $\begin{array}{c}\text { Weather ed } \\
(600 \mathrm{C})\end{array}$ & $\begin{array}{c}\text { dried } \\
\text { Saturated } \\
\text { Soepage }\end{array}$ & $\begin{array}{l}14.7(11.1) \\
14.7(11.1) \\
14.7(11.1)\end{array}$ & \begin{tabular}{|l}
$28.4(21.9)$ \\
$28.4(21.9)$ \\
$28.4(21.9)$ \\
\end{tabular} & $\begin{array}{l}1.93 \\
2.21 \\
2.21 \\
\end{array}$ & $4.03 \times 10^{-9}$ & $8.05 \times 10^{-7}$ & $\begin{array}{l}0.887 \\
1.201 \\
1.201 \\
\end{array}$ \\
\hline \multirow{4}{*}{ Shales } & \multirow{2}{*}{$\begin{array}{l}\text { Wakayamo } \\
\text { Prefecture } \\
\text { (heet flow } \\
\text { normal to } \\
\text { layers) }\end{array}$} & $s-1$ & \begin{tabular}{c|} 
non- \\
Weather ed
\end{tabular} & \begin{tabular}{|c|} 
dried \\
Satur at tod \\
Seepage
\end{tabular} & $\begin{array}{l}0.129 \\
0.129 \\
0.129 \\
\end{array}$ & $\begin{array}{l}0.527 \\
0.527 \\
0.527 \\
\end{array}$ & $\begin{array}{l}2.74 \\
2.75 \\
2.75 \\
\end{array}$ & & & $\begin{array}{l}0.921 \\
0.867 \\
0.867\end{array}$ \\
\hline & & $s-2$ & $\begin{array}{c}\text { Weather ed } \\
(200 \mathrm{C})\end{array}$ & $\begin{array}{c}\text { dried } \\
\text { Soturated } \\
\text { Seepage }\end{array}$ & \begin{tabular}{|l|}
$0.196(0.181)$ \\
$0.196(0.181)$ \\
$0.196(0.181)$ \\
\end{tabular} & $\begin{array}{l}0.538(0.497) \\
0.538(0.497) \\
0.538(0.497)\end{array}$ & $\begin{array}{l}2.74 \\
2.74 \\
2.74 \\
\end{array}$ & & & $\begin{array}{l}0.938 \\
0.837 \\
0.837 \\
\end{array}$ \\
\hline & \multirow{2}{*}{$\begin{array}{l}\text { Wakayamo } \\
\text { Profecture } \\
\text { (heat flow } \\
\text { Parallel to } \\
\text { layers) }\end{array}$} & $s-3$ & $\begin{array}{c}\text { non- } \\
\text { Weather ed }\end{array}$ & $\begin{array}{c}\text { dried } \\
\text { Saturated } \\
\text { Soepage }\end{array}$ & $\begin{array}{l}0.211 \\
0.211 \\
0.211 \\
\end{array}$ & $\begin{array}{l}0.589 \\
0.589 \\
0.589 \\
\end{array}$ & $\begin{array}{l}2.80 \\
2.80 \\
2.80\end{array}$ & & & $\begin{array}{l}0.925 \\
0.946 \\
0.946\end{array}$ \\
\hline & & $5-4$ & $\begin{array}{l}\text { Weathered } \\
\left(200^{\circ}\right)\end{array}$ & $\begin{array}{c}\text { dried } \\
\text { Saturated } \\
\text { Seepage }\end{array}$ & \begin{tabular}{|l|}
$0.188(0.177)$ \\
$0.188(0.177)$ \\
$0.188(0.177)$ \\
\end{tabular} & $\begin{array}{l}0.517(0.489) \\
0.517(0.489) \\
0.517(0.489)\end{array}$ & $\begin{array}{l}2.75 \\
2.76 \\
2.76 \\
\end{array}$ & & & $\begin{array}{l}0.917 \\
0.867 \\
0.867\end{array}$ \\
\hline \multirow{6}{*}{ Tuffs } & \multirow{2}{*}{$\begin{array}{c}\text { Fukushima } \\
\text { Prefocture } \\
\text { (Shirakawa } \\
\text { tuff) }\end{array}$} & $T-1$ & $\begin{array}{c}\text { non- } \\
\text { Weather ed }\end{array}$ & $\begin{array}{c}\text { dried } \\
\text { Saturated } \\
\text { Seepage }\end{array}$ & $\begin{array}{l}9.43 \\
9.43 \\
9.43 \\
\end{array}$ & $\begin{array}{l}19.5 \\
19.5 \\
19.5 \\
\end{array}$ & $\begin{array}{l}2.06 \\
2.26 \\
2.26 \\
\end{array}$ & $9.18 \times 10^{-10}$ & $6.59 \times 10^{-7}$ & $\begin{array}{l}0.841 \\
0.971 \\
0.971 \\
\end{array}$ \\
\hline & & $T-2$ & $\begin{array}{c}\text { Weather ed } \\
(600 \mathrm{C})\end{array}$ & $\begin{array}{c}\text { dried } \\
\text { Saturated } \\
\text { Seepage }\end{array}$ & $\begin{array}{l}11.1 \\
11.1 \\
11.1 \\
\end{array}$ & $\begin{array}{l}22.8(19.5) \\
22.8(19.5) \\
22.8(19.5)\end{array}$ & $\begin{array}{l}2.05 \\
2.27 \\
2.27 \\
\end{array}$ & $5.54 \times 10^{-9}$ & $3.08 \times 10^{-6}$ & $\begin{array}{l}0.787 \\
0.984 \\
0.984 \\
\end{array}$ \\
\hline & \multirow{2}{*}{$\begin{array}{c}\text { Fukushima } \\
\text { Prefecture } \\
\text { (Emochi } \\
\text { tuff) }\end{array}$} & $T-3$ & $\begin{array}{c}\text { non- } \\
\text { Weather ed }\end{array}$ & \begin{tabular}{|c|} 
dried \\
Saturated \\
Soepage
\end{tabular} & $\begin{array}{l}11.3 \\
11.3 \\
11.3 \\
\end{array}$ & $\begin{array}{l}22.8 \\
22.8 \\
22.8 \\
\end{array}$ & $\begin{array}{l}2.01 \\
2.24 \\
2.24 \\
\end{array}$ & $2.14 \times 10^{-8}$ & $1.19 \times 10^{-5}$ & $\begin{array}{l}0.812 \\
1.000 \\
1.000\end{array}$ \\
\hline & & $T-4$ & $\begin{array}{l}\text { Weathered } \\
(600 \mathrm{C})\end{array}$ & $\begin{array}{c}\text { dried } \\
\text { Saturatod } \\
\text { Seepage }\end{array}$ & $\begin{array}{l}12.5 \\
12.5 \\
12.5 \\
\end{array}$ & $\begin{array}{l}25.0(22.6) \\
25.0(22.6) \\
25.0(22.6)\end{array}$ & $\begin{array}{l}1.99 \\
2.24 \\
2.24 \\
\end{array}$ & $6.85 \times 10^{-8}$ & $4.02 \times 10^{-5}$ & $\begin{array}{l}0.804 \\
1.034 \\
1.034\end{array}$ \\
\hline & \multirow{2}{*}{$\begin{array}{l}\text { Tochigi } \\
\text { Prefecture } \\
\text { (Ohya } \\
\text { stone) }\end{array}$} & $T-5$ & $\begin{array}{c}\text { non- } \\
\text { Weather ed }\end{array}$ & $\begin{array}{c}\text { dried } \\
\text { Saturated } \\
\text { Seepage }\end{array}$ & $\begin{array}{l}9.04 \\
9.04 \\
9.04 \\
\end{array}$ & $\begin{array}{l}30.2 \\
30.2 \\
30.2 \\
\end{array}$ & $\begin{array}{l}1.45 \\
1.75 \\
1.75\end{array}$ & & & $\begin{array}{l}1.113 \\
1.457 \\
1.457\end{array}$ \\
\hline & & $T-6$ & $\begin{array}{c}\text { Weather ed } \\
\left(600^{\circ} \mathrm{C}\right)\end{array}$ & $\begin{array}{c}\text { dried } \\
\text { Saturated } \\
\text { Seepage }\end{array}$ & $\begin{array}{r}33.0 \\
33.0 \\
33.0 \\
\end{array}$ & $\begin{array}{l}43.3(34.8) \\
43.3(34.8) \\
43.3(34.8)\end{array}$ & $\begin{array}{l}1.39 \\
1.82 \\
1.82\end{array}$ & $1.17 \times 10^{-7}$ & $1.01 \times 10^{-5}$ & $\begin{array}{l}1.139 \\
1.348 \\
1.348\end{array}$ \\
\hline \multirow[t]{2}{*}{ Andesite } & \multirow{2}{*}{$\begin{array}{l}\text { Kanagawa } \\
\text { Prefecture }\end{array}$} & $A-1$ & \begin{tabular}{|c|} 
non- \\
Weather ed
\end{tabular} & \begin{tabular}{c|} 
dried \\
Saturated \\
Seepage
\end{tabular} & $\begin{array}{l}9.63 \\
9.63 \\
9.63 \\
\end{array}$ & $\begin{array}{l}19.6 \\
19.6 \\
19.6 \\
\end{array}$ & $\begin{array}{l}2.17 \\
2.37 \\
2.37\end{array}$ & $5.44 \times 10^{-7}$ & $2.37 \times 10^{-5}$ & $\begin{array}{l}0.820 \\
0.896 \\
0.896\end{array}$ \\
\hline & & $A-2$ & $\begin{array}{c}\text { Weather ed } \\
(600 \mathrm{r})\end{array}$ & $\begin{array}{c}\text { dried } \\
\text { Saturated } \\
\text { Seepage }\end{array}$ & $\begin{array}{l}10.3 \\
10.3 \\
10.3\end{array}$ & $\begin{array}{l}21.9(20.6) \\
21.9(20.6) \\
21.9(20.6)\end{array}$ & $\begin{array}{l}2.11 \\
2.33 \\
2.33\end{array}$ & $2.67 \times 10^{-5}$ & $1.22 \times 10^{-4}$ & $\begin{array}{l}0.846 \\
0.933 \\
0.933\end{array}$ \\
\hline
\end{tabular}

Note: Values of water absorbing capacity and porosity in bracket are those of initial condition before weatherine. 
(b) Results of measurement

\begin{tabular}{|c|c|c|c|c|c|c|c|c|c|c|}
\hline \multirow{2}{*}{$\begin{array}{r}\text { Name of } \\
\text { rocks }\end{array}$} & \multirow{2}{*}{$\begin{array}{l}\text { Sampling } \\
\text { locations }\end{array}$} & \multirow{2}{*}{$\begin{array}{l}\text { Sample } \\
\text { number }\end{array}$} & \multirow{2}{*}{$\begin{array}{l}\text { Weathering } \\
\text { conditions }\end{array}$} & \multirow{2}{*}{$\begin{array}{l}\text { Testing } \\
\text { conditions }\end{array}$} & \multicolumn{3}{|c|}{$\begin{array}{l}\text { Thermal conductivities } \\
(w / m \cdot k)\end{array}$} & \multicolumn{3}{|c|}{$\begin{array}{l}\text { Thermal diffusivities } \\
\left(\times 10^{-6} \mathrm{~m}^{2} / \mathrm{s}\right)\end{array}$} \\
\hline & & & & & $x_{1}=0.05 \mathrm{~m}$ & $x_{2}=0.10 \mathrm{~m}$ & Average & $x_{1}=0.05 \mathrm{~m}$ & $x_{2}=0.10 \mathrm{~m}$ & Average \\
\hline \multirow{4}{*}{ Granites } & \multirow{2}{*}{$\begin{array}{c}\text { Ibaraki } \\
\text { Prefecture }\end{array}$} & $G-1$ & $\begin{array}{l}\text { non- } \\
\text { Weathered }\end{array}$ & $\begin{array}{c}\text { dried } \\
\text { Saturated } \\
\text { Seepage }\end{array}$ & $\begin{array}{l}1.48 \\
1.79 \\
- \\
\end{array}$ & $\begin{array}{l}2.07 \\
2.09 \\
\end{array}$ & $\begin{array}{l}1.78 \\
1.94 \\
- \\
\end{array}$ & $\begin{array}{c}0.694 \\
0.833 \\
\end{array}$ & $\begin{array}{c}0.972 \\
0.972 \\
\end{array}$ & $\begin{array}{l}0.833 \\
0.903 \\
\end{array}$ \\
\hline & & $\mathbf{G}-\mathbf{2}$ & $\begin{array}{l}\text { Weathered } \\
\left(600^{\circ} \mathrm{C}\right)\end{array}$ & $\begin{array}{c}\text { dried } \\
\text { Saturated } \\
\text { Seepage } \\
\end{array}$ & $\begin{array}{l}2.05 \\
2.00 \\
1.94 \\
\end{array}$ & $\begin{array}{l}1.93 \\
1.81 \\
1.94 \\
\end{array}$ & $\begin{array}{l}1.99 \\
1.91 \\
1.94\end{array}$ & $\begin{array}{l}0.972 \\
0.917 \\
0.889\end{array}$ & $\begin{array}{l}0.917 \\
0.833 \\
0.889 \\
\end{array}$ & $\begin{array}{l}0.945 \\
0.875 \\
0.889\end{array}$ \\
\hline & \multirow{2}{*}{$\begin{array}{l}\text { Okayama } \\
\text { Prefecture }\end{array}$} & $\mathbf{G}-\mathbf{3}$ & $\begin{array}{c}\text { non- } \\
\text { Weathered }\end{array}$ & $\begin{array}{c}\text { dried } \\
\text { Saturated } \\
\text { Seepage }\end{array}$ & $\begin{array}{l}2.21 \\
2.38 \\
\end{array}$ & $\begin{array}{l}2.40 \\
2.56 \\
\end{array}$ & $\begin{array}{l}2.30 \\
2.48 \\
\end{array}$ & $\begin{array}{l}1.03 \\
1.14 \\
\end{array}$ & $\begin{array}{l}1.11 \\
1.22\end{array}$ & $\begin{array}{l}1.07 \\
1.18 \\
\end{array}$ \\
\hline & & $G-4$ & $\begin{array}{l}\text { Weathered } \\
\left(6000^{\circ}\right)\end{array}$ & $\begin{array}{c}\text { dried } \\
\text { Saturated } \\
\text { Seepage }\end{array}$ & $\begin{array}{l}1.97 \\
2.38 \\
1.61 \\
\end{array}$ & $\begin{array}{l}1.97 \\
2.38 \\
1.61 \\
\end{array}$ & $\begin{array}{l}1.97 \\
2.38 \\
1.61 \\
\end{array}$ & $\begin{array}{l}0.919 \\
1.03 \\
0.694 \\
\end{array}$ & $\begin{array}{l}0.919 \\
1.03 \\
0.694 \\
\end{array}$ & $\begin{array}{l}0.917 \\
1.03 \\
0.694\end{array}$ \\
\hline \multirow{2}{*}{ Basalt } & \multirow{2}{*}{$\begin{array}{c}\text { Hyogo } \\
\text { Prefecture }\end{array}$} & $B-1$ & $\begin{array}{c}\text { non- } \\
\text { Weathered }\end{array}$ & $\begin{array}{c}\text { dried } \\
\text { Saturated } \\
\text { Seepage }\end{array}$ & $\begin{array}{l}1.70 \\
2.34 \\
\end{array}$ & $\begin{array}{l}1.86 \\
2.09 \\
\end{array}$ & $\begin{array}{l}1.78 \\
2.21 \\
\end{array}$ & $\begin{array}{l}0.833 \\
1.06 \\
\end{array}$ & $\begin{array}{l}0.915 \\
0.944\end{array}$ & $\begin{array}{l}0.875 \\
1.00 \\
\end{array}$ \\
\hline & & $B-2$ & $\begin{array}{l}\text { Weathered } \\
\left(600^{\circ} \mathrm{C}\right)\end{array}$ & $\begin{array}{c}\text { dried } \\
\text { Saturated } \\
\text { Seepage }\end{array}$ & $\begin{array}{l}1.45 \\
2.02 \\
1.71\end{array}$ & $\begin{array}{l}1.57 \\
1.84 \\
1.71\end{array}$ & $\begin{array}{l}151 \\
193 \\
1.71\end{array}$ & $\begin{array}{l}0.722 \\
0.885 \\
0.750\end{array}$ & $\begin{array}{l}0.778 \\
0.806 \\
0.750\end{array}$ & $\begin{array}{l}0.750 \\
0.847 \\
0.750\end{array}$ \\
\hline \multirow{4}{*}{$\begin{array}{l}\text { Sand- } \\
\text { Stones }\end{array}$} & \multirow{2}{*}{$\begin{array}{c}\text { Chiba } \\
\text { Prefecture } \\
\text { (Coarse } \\
\text { grains) }\end{array}$} & $S a-1$ & $\begin{array}{l}\text { non- } \\
\text { Weathered }\end{array}$ & $\begin{array}{c}\text { dried } \\
\text { Saturated } \\
\text { Seepage }\end{array}$ & $\begin{array}{l}0.691 \\
1.49 \\
1.13 \\
\end{array}$ & $\begin{array}{l}0.783 \\
1.49 \\
1.13\end{array}$ & $\begin{array}{l}0.737 \\
1.49 \\
1.13\end{array}$ & $\begin{array}{l}0.417 \\
0.474 \\
0.361\end{array}$ & $\begin{array}{l}0.472 \\
0.474 \\
0.361 \\
\end{array}$ & $\begin{array}{l}0.444 \\
0.474 \\
0.361\end{array}$ \\
\hline & & $\mathrm{Sa}-2$ & $\begin{array}{l}\text { Weathered } \\
\left(600^{\circ}\right)\end{array}$ & $\begin{array}{c}\text { dried } \\
\text { Saturated } \\
\text { Seepage }\end{array}$ & $\begin{array}{l}0.745 \\
1.21 \\
0.907\end{array}$ & $\begin{array}{l}0.745 \\
1.21 \\
0.907\end{array}$ & $\begin{array}{l}0.745 \\
1.21 \\
0.907\end{array}$ & $\begin{array}{l}0.500 \\
0.444 \\
0.333\end{array}$ & $\begin{array}{l}0.500 \\
0.444 \\
0.333\end{array}$ & $\begin{array}{l}0.500 \\
0.444 \\
0.333\end{array}$ \\
\hline & \multirow{2}{*}{$\begin{array}{c}\text { Chiba } \\
\text { Prefecture } \\
\text { (fine grains) }\end{array}$} & $\mathrm{Sa}-3$ & $\begin{array}{l}\text { non- } \\
\text { Weathered }\end{array}$ & $\begin{array}{c}\text { dried } \\
\text { Saturated } \\
\text { Seepage }\end{array}$ & $\begin{array}{l}1.07 \\
1.99 \\
\end{array}$ & $\begin{array}{l}1.27 \\
1.99 \\
\end{array}$ & $\begin{array}{l}1.16 \\
1.99 \\
\end{array}$ & $\begin{array}{l}0.611 \\
0.806\end{array}$ & $\begin{array}{l}0.722 \\
0.806\end{array}$ & $\begin{array}{l}0.667 \\
0.806\end{array}$ \\
\hline & & $S a-4$ & $\begin{array}{l}\text { Weathered } \\
\left(600^{\circ} \mathrm{C}\right)\end{array}$ & $\begin{array}{c}\text { dried } \\
\text { Saturated } \\
\text { Seepage }\end{array}$ & $\begin{array}{l}1.34 \\
1.92 \\
1.33 \\
\end{array}$ & $\begin{array}{l}1.34 \\
1.92 \\
1.33\end{array}$ & $\begin{array}{l}1.34 \\
1.92 \\
1.33 \\
\end{array}$ & $\begin{array}{l}0.778 \\
0.722 \\
0.500\end{array}$ & $\begin{array}{l}0.778 \\
0.722 \\
0.500\end{array}$ & $\begin{array}{l}0.778 \\
0.722 \\
0.500\end{array}$ \\
\hline \multirow{4}{*}{ Shales } & \multirow{2}{*}{$\begin{array}{c}\text { Wakayama } \\
\text { Prefecture } \\
\text { (heat flow } \\
\text { normal to } \\
\text { layers) }\end{array}$} & $s-1$ & $\begin{array}{c}\text { non- } \\
\text { Weathered }\end{array}$ & $\begin{array}{c}\text { dried } \\
\text { Saturated } \\
\text { Seepage }\end{array}$ & $\begin{array}{l}2.45 \\
2.71 \\
\end{array}$ & $\begin{array}{l}2.73 \\
2.91\end{array}$ & $\begin{array}{l}2.59 \\
2.81\end{array}$ & $\begin{array}{l}0.972 \\
1.14\end{array}$ & $\begin{array}{l}1.08 \\
1.22 \\
\end{array}$ & $\begin{array}{l}1.03 \\
1.18 \\
\end{array}$ \\
\hline & & $s-2$ & $\begin{array}{c}\text { Weathered } \\
\left(200^{\circ} \mathrm{C}\right)\end{array}$ & $\begin{array}{c}\text { dried } \\
\text { Saturated } \\
\text { Seepage }\end{array}$ & $\begin{array}{l}3.00 \\
2.67 \\
- \\
\end{array}$ & $\begin{array}{l}3.00 \\
2.67 \\
\end{array}$ & $\begin{array}{l}3.00 \\
2.67\end{array}$ & $\begin{array}{l}1.17 \\
1.17 \\
\end{array}$ & $\begin{array}{l}1.17 \\
1.17 \\
\end{array}$ & $\begin{array}{l}1.17 \\
1.17\end{array}$ \\
\hline & \multirow{2}{*}{$\begin{array}{c}\text { Wakayama } \\
\text { Prefecture } \\
\text { (heat flow } \\
\text { Parllel to } \\
\text { layers) }\end{array}$} & $s-3$ & $\begin{array}{c}\text { non- } \\
\text { Weathered }\end{array}$ & $\begin{array}{c}\text { dried } \\
\text { Saturated } \\
\text { Seepage }\end{array}$ & $\begin{array}{r}2.88 \\
3.16 \\
\end{array}$ & $\begin{array}{l}3.02 \\
3.16 \\
\end{array}$ & $\begin{array}{l}2.95 \\
3.16 \\
\end{array}$ & $\begin{array}{l}1.11 \\
1.19 \\
\end{array}$ & $\begin{array}{l}1.17 \\
1.19 \\
\end{array}$ & $\begin{array}{l}1.14 \\
1.19 \\
\end{array}$ \\
\hline & & $s-4$ & $\begin{array}{c}\text { Weathered } \\
\left(200^{\circ} \mathrm{C}\right)\end{array}$ & $\begin{array}{c}\text { dried } \\
\text { Saturated } \\
\text { Seepage }\end{array}$ & $\begin{array}{r}2.94 \\
2.66 \\
\end{array}$ & $\begin{array}{l}3.08 \\
2.79 \\
\end{array}$ & $\begin{array}{r}3.01 \\
2.72 \\
\end{array}$ & $\begin{array}{l}1.17 \\
1.11 \\
\end{array}$ & $\begin{array}{l}1.22 \\
1.17 \\
\end{array}$ & $\begin{array}{r}1.19 \\
1.14 \\
\end{array}$ \\
\hline \multirow{6}{*}{ Tuffs } & \multirow{2}{*}{$\begin{array}{c}\text { Fukushima } \\
\text { Prefecture } \\
\text { (Shirakawa } \\
\text { tuff) }\end{array}$} & $T-1$ & $\begin{array}{c}\text { non- } \\
\text { Weathered }\end{array}$ & $\begin{array}{c}\text { dried } \\
\text { Saturated } \\
\text { Seepage }\end{array}$ & $\begin{array}{l}1.08 \\
1.83 \\
1.28\end{array}$ & $\begin{array}{l}1.33 \\
1.71 \\
1.34 \\
\end{array}$ & $\begin{array}{l}1.21 \\
1.77 \\
1.31\end{array}$ & $\begin{array}{l}0.625 \\
0.833 \\
0.583\end{array}$ & $\begin{array}{l}0.764 \\
0.778 \\
0.611\end{array}$ & $\begin{array}{l}0.694 \\
0.806 \\
0.597\end{array}$ \\
\hline & & $T-2$ & $\begin{array}{l}\text { Weathered } \\
\left(600^{\circ} \mathrm{C}\right)\end{array}$ & $\begin{array}{c}\text { dried } \\
\text { Saturated } \\
\text { Seepage }\end{array}$ & $\begin{array}{l}0.826 \\
1.44 \\
1.15 \\
\end{array}$ & $\begin{array}{l}0.896 \\
1.43 \\
1.24\end{array}$ & $\begin{array}{l}0.861 \\
1.43 \\
1.20\end{array}$ & $\begin{array}{l}0.514 \\
0.644 \\
0.514\end{array}$ & $\begin{array}{l}0.556 \\
0.639 \\
0.556\end{array}$ & $\begin{array}{l}0.535 \\
0.642 \\
0.535\end{array}$ \\
\hline & \multirow{2}{*}{$\begin{array}{c}\text { Fukushima } \\
\text { Prefecture } \\
\text { (Emochi } \\
\text { tuf } f \text { ) }\end{array}$} & $T-3$ & $\begin{array}{c}\text { non- } \\
\text { Weathered }\end{array}$ & $\begin{array}{c}\text { dried } \\
\text { Saturated } \\
\text { Seepage }\end{array}$ & $\begin{array}{l}0.512 \\
1.12 \\
1.37\end{array}$ & $\begin{array}{l}0.814 \\
1.37 \\
1.37\end{array}$ & $\begin{array}{l}0.663 \\
1.24 \\
1.37 \\
\end{array}$ & $\begin{array}{l}0.319 \\
0.500 \\
0.611 \\
\end{array}$ & $\begin{array}{l}0.500 \\
0.611 \\
0.611\end{array}$ & $\begin{array}{l}0.410 \\
0.556 \\
0.611 \\
\end{array}$ \\
\hline & & $T-4$ & $\begin{array}{l}\text { Weathered } \\
\left(600^{\circ} \mathrm{C}\right)\end{array}$ & $\begin{array}{c}\text { dried } \\
\text { Saturated } \\
\text { Seepage }\end{array}$ & $\begin{array}{l}0.930 \\
1.67 \\
2.19 \\
\end{array}$ & $\begin{array}{l}1.07 \\
1.67 \\
1.93\end{array}$ & $\begin{array}{l}1.00 \\
1.67 \\
2.06\end{array}$ & $\begin{array}{l}0.583 \\
0.722 \\
0.944\end{array}$ & $\begin{array}{l}0.667 \\
0.722 \\
0.833\end{array}$ & $\begin{array}{l}0.625 \\
0.722 \\
0.889 \\
\end{array}$ \\
\hline & \multirow{2}{*}{$\begin{array}{c}\text { Tochigi } \\
\text { Prefecture } \\
\text { (Onya } \\
\text { stone) }\end{array}$} & $T-5$ & $\begin{array}{c}\text { non- } \\
\text { Weathered }\end{array}$ & $\begin{array}{c}\text { dried } \\
\text { Saturated } \\
\text { Seepage }\end{array}$ & $\begin{array}{l}0.454 \\
1.70 \\
\end{array}$ & $\begin{array}{l}0.628 \\
1.28 \\
\end{array}$ & $\begin{array}{l}0.535 \\
1.49 \\
\end{array}$ & $\begin{array}{l}0.278 \\
0.667\end{array}$ & $\begin{array}{l}0.389 \\
0.500\end{array}$ & $\begin{array}{l}0.333 \\
0.611 \\
\end{array}$ \\
\hline & & $T-6$ & $\begin{array}{c}\text { Weathered } \\
(600 \mathrm{C})\end{array}$ & $\begin{array}{c}\text { dried } \\
\text { Saturated } \\
\text { Seepage }\end{array}$ & $\begin{array}{l}0.523 \\
0.779 \\
1.09 \\
\end{array}$ & $\begin{array}{l}0.686 \\
0.849 \\
1.03\end{array}$ & $\begin{array}{l}0.605 \\
0.814 \\
1.14\end{array}$ & $\begin{array}{l}0.333 \\
0.319 \\
0.444\end{array}$ & $\begin{array}{l}0.431 \\
0.347 \\
0.486 \\
\end{array}$ & $\begin{array}{l}0.383 \\
0.333 \\
0.467\end{array}$ \\
\hline \multirow{2}{*}{ Andesite } & \multirow{2}{*}{$\begin{array}{r}\text { Kanagawa } \\
\text { Prefecture }\end{array}$} & $A-1$ & $\begin{array}{c}\text { non- } \\
\text { Wea thered }\end{array}$ & $\begin{array}{c}\text { dried } \\
\text { Saturated } \\
\text { Seepage }\end{array}$ & $\begin{array}{l}0.896 \\
1.42 \\
1.59\end{array}$ & $\begin{array}{l}1.19 \\
1.65 \\
1.77\end{array}$ & $\begin{array}{l}1.05 \\
1.54 \\
1.69 \\
\end{array}$ & $\begin{array}{l}0.500 \\
0.667 \\
0.750\end{array}$ & $\begin{array}{l}0.667 \\
0.778 \\
0.833\end{array}$ & $\begin{array}{l}0.584 \\
0.722 \\
0.792\end{array}$ \\
\hline & & $A-2$ & $\begin{array}{c}\text { Weathered } \\
\left(600^{\circ}\right)\end{array}$ & $\begin{array}{c}\text { dried } \\
\text { Saturated } \\
\text { Seepage }\end{array}$ & $\begin{array}{l}0.919 \\
1.40 \\
2.17\end{array}$ & $\begin{array}{l}1.05 \\
1.48 \\
2.17\end{array}$ & $\begin{array}{l}0.977 \\
1.44 \\
2.17\end{array}$ & $\begin{array}{l}0.514 \\
0.639 \\
1.00\end{array}$ & $\begin{array}{l}0.583 \\
0.681 \\
1.00\end{array}$ & $\begin{array}{l}0.550 \\
0.661 \\
1.00\end{array}$ \\
\hline
\end{tabular}

Note: Seepage flow doesn't occur under maximum pressure $0.98 \mathrm{MN} / \mathrm{m}^{2}$ in case of notation ( - ). 
まず, 乾燥, 飽和状態の岩石試料の熱拡散係数 $a$ の 決定法を式（3）から述べる. 理論解の式 (3) と実験 から得られた温度の経時変化を対比して $a$ を決定する ため, あらかじめ式 $(3)$ に取り得る範囲の $a$ の值を 代入して，トレーシング紙上に $a$ の值をパラメーター にとった解曲線群を描いておくそそこで，この解曲線群 を描いた用紙を実験で得られた温度の経時変化曲線上に 重ねて, best fitting curve を探し出すと, その場合の $a$ の值が求めようとする熱拡散係数である。 その場合, best fitting の判断は $a$ の値に $a \pm 0.05 a$ の範囲内で決 定・選定することとした。した がって，すべての $a$ の值は土 $5 \%$ の範囲内で決定されたも のといえる.このようにして決 定された $a$ の値を用いて得ら れる解曲線と実験曲線の合致程 度はFig. 3(a)，(b) に示して ある．解曲線と実験のそれはよ い一致を示していることがわか る. Table 1 (b) にはこのよう にして得られた $a$ の値を一括 してまとめて揭げてある。また 同時に，熱伝導率 $x$ は， $x=\rho$. $c \cdot a$ から決まりややり Table 1 (b) にまとめて示して ある. Table 1 (b) からわかる ように, 熱拡散係数の值は乾燥 状態において風化岩石の方がク ラックの存在のため自然状態の 値より小さくなっていることが 明白である．さらに，飽和岩石 の方が乾燥状態のそれより熱拡 散係数の值が大きくなっている ことも興味深い。また，岩石の 種類による差異に注目すると， 頁岩の $a$ の値が全体に大きく, 砂岩, 凝灰岩のそれらは小さく なっている、いま，熱伝導率 $x$ および熱拡散係数 $a$ の值と, 空隙率入の関係に注目して, 両者の相関を導入してみること にする. 本実験で得られた と $a$ のすべての值を Table 1 から空隙率とともに読み取り， その相関を示したものが Fig.4, 5 である. Fig. 4, 5 か らわかるように熱伝導率 $x$ と
空隙率 $\lambda$ の関係を

$$
x=\alpha \cdot e^{-\beta \cdot \lambda}
$$

とおき, 熱拡散係数 $a$ と $\lambda$ の関係も同様に

$$
a=\alpha^{\prime} \cdot e^{-\beta^{\prime} \cdot \lambda}
$$

とおく.ここに， $\alpha, \beta, \alpha^{\prime}, \beta^{\prime}$ : 定数である. 式 (8) における $\alpha, \beta$ の值は乾燥岩石について, 相関係数 $R=$ 0.909 で $\alpha=2.39, \beta=0.0348$ となり, 飽和岩石では $R$ $=0.864, \alpha=2.54, \beta=0.0196$ となる. いうまでもなく, «は $\lambda$ の増加により減少し, 乾燥岩石より飽和のそれの 方が $x$ は全体に大きくなることが明瞭である。一方，

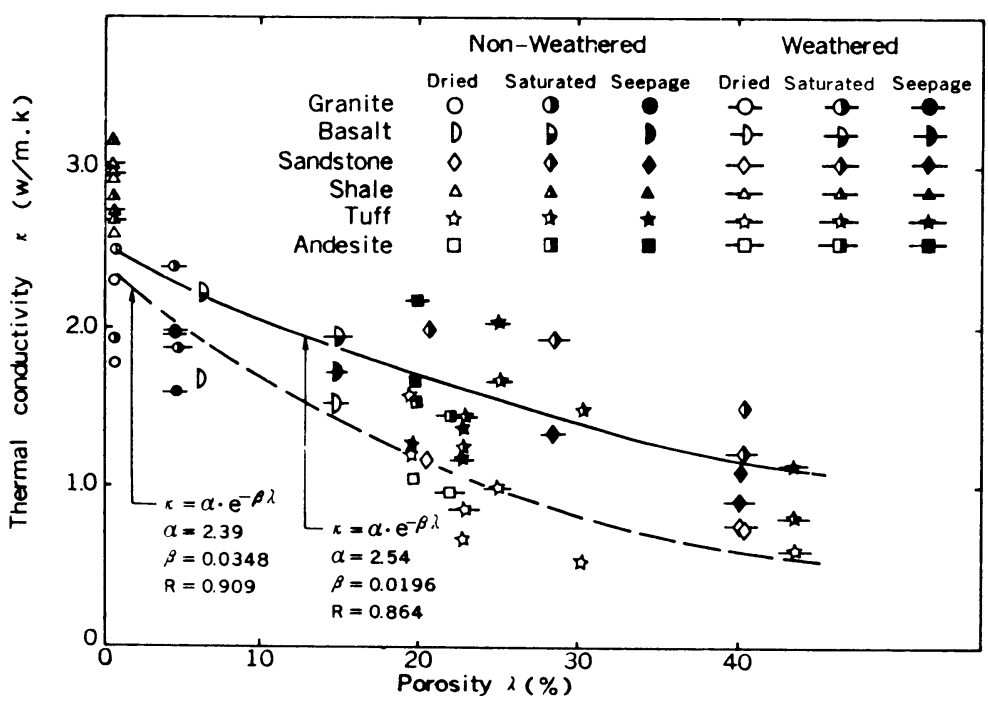

Fig. 4 Relationships between thermal conductivity $(x)$ and porosity $(\lambda)$ in case of dried and saturated rocks.

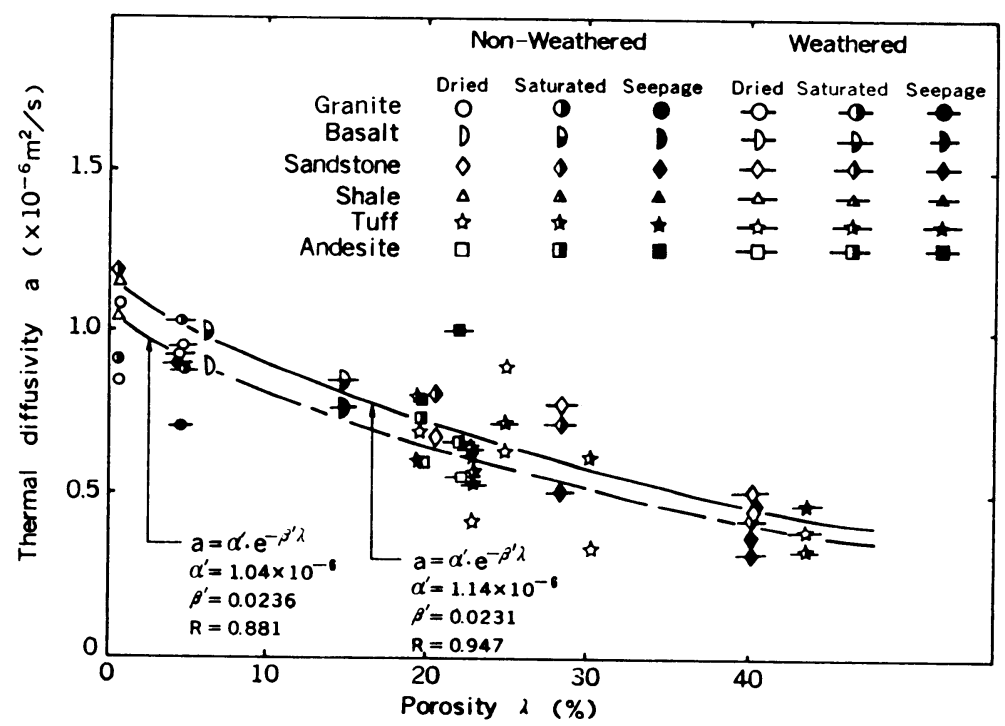

Fig. 5 Relationships between thermal diffusivity $(a)$ and porosity $(\lambda)$ in case of dried and saturated rocks. 
熱拡散係数 $a$ と $\lambda$ の関係についても, 乾燥岩石の場合, $R=0.881, \alpha^{\prime}=1.04 \times 10^{-6}, \beta^{\prime}=0.0236$ となり, 飽和 の場合, $R=0.947, \alpha^{\prime}=1.14 \times 10^{-6}, \beta^{\prime}=0.0231$ となり, $a$ は八の増加につれて減少することがわかり， $x \sim \lambda の$ 場合と同様な傾向となっている. 次に, 熱水浸透を伴う 場合についてみると, Fig. 4, Fig. 5 のいずれの場合も 乾燥岩石や飽和岩石のように一定した傾向を示さず，か なりのばらつきが認められたため, 乾燥岩石, 飽和岩石 のように $\alpha$ や $\beta, R$ は求めていない.

式 ( 8 ),（9）の関係は実用上きわめて有効であって, $\lambda$ がわかれば $x, a$ の值が容易に推察, 概算できる.

次に, 浸透流を伴う場合の熱拡散係数の $a$ の值を式 （6）から亡゙のようにして求めるかを考えてみる.この 場合も基本的には上述した乾燥, 飽和岩石の場合亡同様 であって、あらかじめ式 $(6)$ の解曲線群を $a$ をパラメー ターとしてトレーシング紙上に描いておき, その曲線群 を実験で得られた実験曲線上に重水て, best fitting curve を決定すれば， $a$ の值は決まる，なぜなら，実験 は理論式（6）を得た場合と同じ初期・境界条件のもと で実験が行われたから当然である.このようにして決定 された $a$ の值を用いて, 理論曲線と実験のそれを比較 したものがFig. 3(c) である. 実験結果と理論は非常に よく一致していることが判読できよう.このようにして 得られた $a$ の值は同じく Table 1 にまとめて示されて いる.しかし, 岩石によっては $0.98 \mathrm{MN} / \mathrm{m}^{2}$ の水圧を かけて，1週間ほど放置しても浸透しなかったものも あったのでそのような試料の $a$ の值は決定できなかっ た. Table 1 を参照すると, 浸透流を伴う熱拡散係数の 值は凝灰岩, 花崗岩および玄武岩の場合, 飽和岩のそれ に比べやや大きい值をとっていることは注目に値する. これは岩石の微小クラックの空間構造による流路の分岐 やクラックおよび流速の場所的違いなどによる，いわゆ る流れの場の構造変化を反映しているものと思われる. しかし, 一般論からして, 透水係数の小さい岩石につい ては, 伝熱速度は飽和岩石の場合に比べて大差ないもの と実験値から結論づけられよう。

\section{5. 結 論}

岩種, 風化の程度, および水理条件による岩石の伝熱 パラメーターは岩盤の伝熱問題を考える際に重要となる ことは冒頭に述べた。
本研究ではこのような伝熱の基本となるパラメーター を特殊設計された装置によっていかに決定するか, それ ら諸パラメータ一間の関係がどうなるか, 本邦で代表的 な 6 種の岩石を用い 66 個について害験的に研究した。

本研究で得られた結論は次のように要約される.

（1）本論で用いた 2 種の特殊実験装置は岩石の伝熱 パラメーターの決定に有効であった。

（2）乾燥状態の岩石の熱拡散係数, 熱伝導率はク ラック・割れ目の存在によって減少する.

（3）飽和状態の岩石の熱拡散係数はクラック・割れ 目の存在によって増加し, 強制対流によっても増加する.

（4）熱伝導率, 熱拡散係数は空隙率の増加によって 指数関数式に従って減少するという結果を得た.

（5）熱拡散係数は花崗岩で $0.694 \times 10^{-6} \sim 1.18 \times$ $10^{-6} \mathrm{~m}^{2} / \mathrm{s}$, 玄武岩で $0.750 \times 10^{-6} \sim 1.00 \times 10^{-6} \mathrm{~m}^{2} / \mathrm{s}$, 砂 岩で $0.333 \times 10^{-6} \sim 0.806 \times 10^{-6} \mathrm{~m}^{2} / \mathrm{s}$ ，凝灰岩で $0.333 \times$ $10^{-6} \sim 0.889 \times 10^{-6} \mathrm{~m}^{2} / \mathrm{s}$ ，および安山岩で $0.55 \times 10^{-6} \sim$ $1.00 \times 10^{-6} \mathrm{~m}^{2} / \mathrm{s}$ の範囲であった.

\section{参 考 文 献}

1) Kunii, D. and Smith, J. M. : Thermal Conductivities of porous rocks filled with stagnant fluid, J. Soc. Petro. Eng., Vol. 1, pp. 37 42, 1961.

2) Combarnous, M. and Bories, S. : Hydrothermal convection in saturated porous media, Advances in Hydroscience, edited by Ven te Chow, Vol.10, Academic Press, pp. 231 307, 1975.

3）松本順一郎・大久保俊治：土の伝熱特性に関する実験的 研究, 土木学会論文報告集, 第 257 号, pp. 53 60, 1977.

4）佐藤邦明・佐々木康夫 : 岩石・岩盤の伝熱パラメーター の測定について, 土質工学会「土と基礎」, Vol. 32, No. 3, pp. $47 \sim 52,1984$.

5）佐藤邦明：飽和多孔体及び温水浸透流における温度伝導 率の実験的決定, 土木学会論文報告集, 第 320 号, pp. $57 \sim 65,1982$.

6) Firdauss, M., Maalej, M. and Belin, B. : Identification of the soil thermal diffusivity from the temperature in situ measurements in a semi-arid region, Numerical Methods in Thermal Problems, Proc. 3th International Conference, Pineridge Press, VK. pp. 219 226, 1983.

7）佐藤邦明・佐々木康夫：岩盤熱水浸透流における温度伝 導率の実験的研究, 第 27 回土木学会水理講演会論文集, pp. 253 258, 1983.

8）佐藤邦明：多孔媒体中の熱輸送に関する実験的研究，第 26 回土木学会水理講演会論文集, pp. 595 600, 1982.

(1984.2.25 - 受付) 